Joanna Johnson, Topographies of Caribbean Writing, Race, and the British Countryside. Cham, Switzerland: Palgrave Macmillan, 2019. xi + 19o pp. (Cloth US\$74.99)

In this engaging study, Joanna Johnson examines the evolution of Caribbean writers' representations of the English countryside from the 1920 s to the present. As she observes, first-generation writers such as Jean Rhys (Dominica), V.S. Naipaul (Trinidad), Derek Walcott (St. Lucia), and Grace Nichols (resident in Britain but born in Guyana), shaped by a British colonial education and imposed notions of "British" landscape in their native lands, developed conceptualizations of England that changed and shifted when they experienced England first-hand. Writers who were "reading their schoolbook English literature in the Caribbean would have had a strong sense of the importance of the British countryside" (p. 5). She argues persuasively that these writers "use the countryside as a medium to interrogate belonging" (p.32) through their engagement with literary tradition, its "form, aesthetics, literary and canonical discrimination, and aesthetic judgements" (p. 33). In contrast, second-generation, British-born writers such as Andrea Levy, Caryl Phillips, and Charlotte Williams represent the countryside with less ambivalence, even as they sometimes find it as "hostile and unwelcoming" as their predecessors did, and even as their protagonists "remain at the margins, continuing to struggle to fit into English countryside village life" (pp. 33-34).

Johnson focuses mainly on the first-generation writers, whose lived experience of the landscape and culture of their Caribbean homelands shapes their representations of Britain and sharpens their need to negotiate issues of belonging. Rhys, for example, famously disliked England, and Johnson ably charts how Voyage in the Dark and Wide Sargasso Sea illustrate the disconnect the protagonists experienced between the England they imagined and its lived reality. Rhys did not like writing about places, Johnson observes; instead, "topographical description allows ... characters to articulate aspects of their

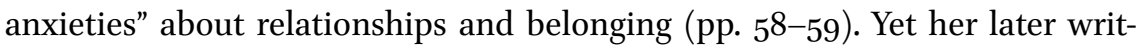
ing evidences her ability to apply her memories of Dominica to England and thereby come to (some) terms with England as home.

By contrast, the move to England serves as a means of recreation and rebirth for Naipaul, who viewed Trinidad as "the landscape of anxiety, even panic and sacrifice" (cited, p. 68) and was only able to appreciate his native land after recreating it in fiction. His appreciation of the British countryside in The Enigma of Arrival similarly develops through the act of creation, whether his own writing or the literary and visual representations of other, primarily British, writers and artists. At the same time, childhood experiences in Trinidad emerge and inform his understanding of the Wiltshire landscape, 
which "includes a Caribbean aesthetic, one that has been heavily informed by [his] rural Trinidadian upbringing" (p. 9o). Walcott's representations of the landscape hearken back to those of Rhys; his depictions of the British countryside are in dialogue with those of the Caribbean, to the detriment of the former. Through meter, rhythm, and other poetic devices, however, Walcott pays homage to English pastoral poetry.

Johnson's chapter on Nichols serves as a bridge between first- and secondgeneration writers. She notes that Nichols's poetry "reveals a continued challenge to the English countryside she describes" (p. 132), a challenge expressed through a Caribbean lexis and figurations of the tropics. Her more recent work is reminiscent of collage in its piecing together of multiple influences, "embracing the different strands that make her up" (p. 132). In this, she anticipates the second-generation writers, whose childhoods find them more at ease in Britain. Even so, Johnson notes that Levy and Phillips both draw sharp distinctions between urban and rural Britain, portraying rural England as discomforting if not explicitly hostile to their characters. Hence for Levy the pub, the legendary site of coziness and community, functions as an unpleasant and even fearful place, underscoring feelings of unbelonging. Williams, on the other hand, recalls Naipaul's The Enigma of Arrival in her depiction of the Welsh countryside through lenses colored by her sojourns in Africa and Guyana. In fact, it was not her Guyanese father but her White British-born mother who stood out as "uncomfortably different" because she was Welsh-speaking, and the way she describes her rural Welsh home is "further complicated by a sense that Wales has been 'colonized'" (p. 156).

Johnson's analysis brings together ecocriticism, postcolonialism, and the emerging field of geocriticism to show how the construction of English national identity is "inextricably connected to understandings of English rurality and countryside" (p. 171). But because that rurality is conflated with Whiteness, English national identity continues to marginalize and exclude those whose race and ethnicity do not conform. As Johnson notes, "The imaginative geographies of these writers' Britain are ones that increasingly allow for their different voices" (p. 174).

\section{Patricia Moran}

Department of English, City University of London, London, UK Patricia.Moran@city.ac.uk 